\title{
Growth hormone improves short stature in children with Shwachman-Diamond syndrome
}

Leczenie hormonem wzrostu istotnie poprawia niski wzrost u dzieci z zespołem

Shwachmana-Diamonda

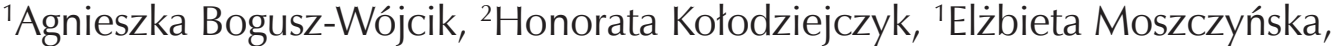 \\ ${ }^{3}$ Maja Klaudel-Dreszler, ${ }^{3}$ Grzegorz Oracz, ${ }^{3}$ Joanna Pawłowska, ${ }^{1,4}$ Mieczysław Szalecki
}

\author{
'Department of Endocrinology and Diabetology, The Children's Memorial Health Institute, Warsaw, Poland \\ ${ }^{2}$ Anthropology Department, The Children's Memorial Health Institute, Warsaw, Poland \\ ${ }^{3}$ Department of Gastroenterology, Hepatology, Feeding Disorders and Paediatrics, The Children's Memorial \\ Health Institute, Warsaw, Poland \\ ${ }^{4}$ Department of Medical Sciences, Collegium Medicum, Poland
}

\begin{abstract}
Introduction: Shwachman-Diamond syndrome (SDS) is a rare, autosomal recessive multisystemic disorder characterized by pancreatic insufficiency and bone marrow failure. Short stature is a recognized feature of SDS syndrome; however, systemic data concerning recombinant human growth hormone $(\mathrm{rGH})$ treatment are limited.

Aim of the study: To assess the effect of rGH treatment in patients with SDS.

Material and Methods: Retrospective data were collected from patients with SDS and growth hormone deficiency (GHD) treated with rGH in the Children's Memorial Health Institute in Warsaw. The annual growth velocity (GV) and height standard deviation score (SD) were compared for up to 2 years of rGH treatment.

Results: Six SDS patients ( $\mathrm{M}: \mathrm{F}=1: 5)$ treated with $\mathrm{rGH}$ were identified. The median age of starting rGH therapy was 7.5 years, with a mean baseline height SD of -4.06 (range: -6.3 to -2.3 SD). The height SD significantly improved to -3.3 ( $p=0.002)$ and then -3.03 ( $p=0.002)$, following 1 and 2 years of treatment, respectively. The average GV for the patients prior to starting treatment was $4.9 \mathrm{~cm} /$ year (range: $3.1-6.5 \mathrm{~cm} /$ year), which significantly improved to $7.6 \mathrm{~cm} /$ year (range: $5.7-9.6 \mathrm{~cm} / \mathrm{year}$ ) after 1 year of rGH treatment $(p=0.020)$ and to $6.7 \mathrm{~cm} /$ year at the end of 2 years.

Conclusions: Our study has shown that rGH treatment significantly improves the height SDS and GV of patients with SDS and GHD without any side effects. Further research is required to analyse the long-term effect of rGH therapy in patients with SDS.

Key words:

growth hormone, short stature, Shwachman-Diamond syndrome.

Streszczenie

Wprowadzenie: Zespół Shwachmana-Diamonda (SDS) jest rzadką, genetycznie uwarunkowaną wieloukładową chorobą, charakteryzującą się niewydolnością zewnątrzwydzielniczą trzustki, zaburzeniami hematologicznymi oraz wadami kośćca. Niskorosłość jest częstą cechą SDS, jednak dane dotyczące leczenia rekombinowanym ludzkim hormonem wzrostu (rGH) są ograniczone.

Cel pracy: Ocena efektów leczenia rGH dzieci z zespołem Shwachmana-Diamonda.

Materiał i metody: Retrospektywne dane zebrano od pacjentów z SDS i niedoborem hormonu wzrostu (GHD) leczonych rGH w Instytucie „Pomnik - Centrum Zdrowia Dziecka” w Warszawie. Roczne tempo wzrastania (GV) i odchylenie standardowe (SD) wzrostu oceniono przez okres 2 lat leczenia rGH.

Wyniki: Zidentyfikowano sześciu pacjentów z SDS (M: K = $1: 5)$ leczonych rGH. Mediana wieku, w którym rozpoczęto terapię rGH, wynosiła 7,5 roku, ze średnim początkowym SD wzrostu wynoszącym -4.06 (zakres: od -6.3 do -2.3 SD). SD wzrostu istotnie poprawiło się do -3.3 SD ( $p=0,002)$, a następnie -3.03 SD ( $p=0,002)$, odpowiednio po roku i dwóch latach leczenia. Średnie GV pacjentów przed rozpoczęciem leczenia wynosiło 4,9 cm/rok (zakres: 3,1-6,5 cm/rok), następnie istotnie wzrosło do 7,6 cm/rok (zakres: 5,7-9,6 cm/rok) po roku leczenia hormonem wzrostu $(p=0,020)$ i do 6,7 cm/rok po 2 latach leczenia.
\end{abstract}


Wnioski: Analiza wykazała, że leczenie rGH znacząco poprawia SD wzrostu i GV u pacjentów z SDS i GHD, bez żadnych skutków ubocznych. Konieczne są dalsze badania, aby przeanalizować długoletnie efekty terapii rGH u pacjentów z SDS.

Słowa kluczowe:

hormon wzrostu, niedobór wzrostu, zespół Shwachmana-Diamonda.

\section{Introduction}

Shwachman-Diamond syndrome (SDS) is a rare autosomal recessive disorder characterized by pancreatic exocrine insufficiency, immune deficiency, bone marrow failure, and skeletal abnormalities [1]. Shwachman-Diamond syndrome is also associated (in about 15\%) with increased risk of developing myelodysplastic syndrome (MDS) and acute myeloid leukaemia (AML) [2].

In 2002, the SBDS gene was described as involved in the syndrome and identified on chromosome $7 q 11$ [3]. The mutations $258+2$ T $>$ C and 183-184TA $>$ CT are found in $>90 \%$ of the affected alleles and are associated with reduced SBDS protein levels [4]. Nevertheless, it has recently been reported that other genes, including DNAJC21, EFL1, and SRP54 are also associated with an SDS-like phenotype [5-7]. All genes associated with SDS are involved in ribosome biogenesis, strengthening the postulate that SDS is a ribosomopathy [4]. Approximately $90 \%$ of patients with clinical manifestations consistent with SDS have mutations of the $S B D S$ gene. However, the negative result of genetic evaluation should not exclude the diagnosis. A precise clinical evaluation is significant to diagnose the presence of the syndrome [1]. SDS is diagnosed on the basis of clinical criteria, namely marrow failure and exocrine pancreatic dysfunction [1]. Significant variability in clinical phenotype, even within families, exists [8]

Short stature is a recognised feature found in approximately $70-80 \%$ of patients with SDS [9-12]. The pathophysiology for short stature in SDS remains unclear. Several clinical studies reported that growth failure is mainly due to inadequate nutrient intake in the presence or in the absence of feeding difficulties, pancreatic insufficiency, and recurrent infections. After diagnosis and the start of an appropriate therapy, the growth rate is restored to a normal level in most of the children with SDS, even though it consistently remains below the third percentile for height and weight [11]. Moreover, some patients with SDS have been diagnosed with growth hormone $(\mathrm{GH})$ deficiency [9-14].

The majority of studies demonstrated that SDS patients present with growth failure; nevertheless, systematic data concerning those features are limited. Therefore, we have decided to examine the effect of recombinant human $\mathrm{GH}(\mathrm{rGH})$ treatment of children with SDS more closely.

The aim of this study is to evaluate the effect of $\mathrm{rGH}$ treatment on a cohort of patients with SDS, GHD, and short stature during the first 2 years of treatment.

\section{Material and methods}

\section{Patients}

The study involved 6 patients ( 5 girls and 1 boy) with SDS and growth hormone deficiency (GHD) treated with $\mathrm{rGH}$ at the
Endocrine Department of the Children's Memorial Health Institute $(\mathrm{CMHI})$ in Warsaw, Poland between 2005 and 2020. The SDS diagnosis was based on the clinical criteria proposed by Dror et al. in 2011 [1] and confirmed by molecular diagnostics in all patients (MEDGEN, Poland).

Data were collected retrospectively from paper medical notes, and information was transferred to an electronic database. The study protocol was consistent with the Helsinki declaration and was approved by the IRB (33/KBE/2018). Written parental consent was obtained in all cases.

\section{Clinical and anthropometric data}

The endocrinological assessment included data on clinical history and physical examination with pubertal staging. Collected information included duration of $\mathrm{rGH}$ treatment to date and growth velocity (GV) in cm/year for each year on medication.

Axiological parameters including body height, weight, and $\mathrm{BMI}\left(\mathrm{w} / \mathrm{h}^{2} ; \mathrm{w}=\right.$ weight in kilograms, $\mathrm{h}=$ height in metres) were collected in all patients following standard protocol. Measurements were undertaken during the outpatient appointments at the Department of Anthropology at $\mathrm{CMHI}$. Data were standardized and referred to the average values of the population of healthy Polish children [15], expressed as standard deviation score (SD) separately for girls and boys, according to the formula: standard deviation score $=(X$ examined $-X$ population $)$ / SD of the population. Short stature was defined as height below -2.0 SD for age and gender. Parental heights were used to calculate mid-parental height (MPH).

Endocrine test results were collected and compared with age-appropriate reference ranges established in the clinical laboratory of $\mathrm{CMHI}$. Growth hormone deficiency (GHD) was diagnosed if stimulated peak of GH on 2 standard stimulation tests (with clonidine, glucagon, and/or arginine) were $<10 \mathrm{ng} / \mathrm{ml}$ (radioimmunoassay). Additionally, all patients underwent IGF-I (radioimmunoassay) and IGFBP-3 (chemiluminescent immunoassay) measurements.

Bone age was analysed using the Greulich and Pyle method.

Exocrine pancreatic insufficiency (EPI) was defined as faecal fat quantities above $5 \mathrm{~g} /$ day. 72-hour-fecal fat quantification used the modified van de Kamer method, which remains the gold standard for diagnosing EPI with fat maldigestion. For faecal fat quantification using modified van de Kamer method, samples were pooled over a 3-day period while consuming their normal diet. Enzyme replacement therapy, if implemented, was withheld 7 days before stool collection. In patients who had more than 1 test, the highest result was taken into consideration [16].

\section{Statistical methods}

The results were analysed with variables expressed as median or mean values and SDS, and statistics were determined 
using the t-test, with a P-value of less than 0.05 being classed as statistically significant.

\section{Results}

Patients' characteristics

Six patients ( $M: F=1: 5)$ with SDS, short stature, and $G H$ deficiency on $\mathrm{rGH}$ therapy were identified and analysed. The average age at the start of the treatment course was 7.5 years (range: 4.8-11.5 years). All patients were of Caucasian and Polish origin with the median age at diagnosis of 5.5 years (range: $0.7-12.5$ years). The median gestational age was 38 weeks (range: $33-41$ weeks) and the median weight at birth was $-1.4 \mathrm{SD}$ (ranging from -2.4 to $-0.8 \mathrm{SD}$ ). All the patients presented with exocrine pancreatic insufficiency and were on pancreatic enzyme replacement therapy during the observation period.

Skeletal abnormalities such as metaphyseal dysostosis, cupping of the anterior ribs, delayed bone age, osteoporosis, clinodactylies, and thoracic dystrophy were found in the analysed group of patients. Thoracic dystrophy led to a preliminary diagnosis of Jeune syndrome or asphyxiating thoracic dystrophy (ATD) in 1 patient. Other endocrinology diseases such as hypothyroidism (2 patients) and congenital hypopituitarism (1 patient) were also diagnosed in this cohort. The patients' characteristics are shown in Table I.

\section{Endocrinologic assessment}

Baseline IGF-1 and IGF-BP3 were assayed before the beginning of treatment, and the mean IGF-1 level was $116.2 \mathrm{ng} / \mathrm{mL}$ (range: 63.4-199 $\mathrm{ng} / \mathrm{ml}$ ), and IGF-BP3 was $2.2 \mu \mathrm{g} / \mathrm{ml}$ (range: $1.5-2.9 \mu \mathrm{g} / \mathrm{ml}$ ). GH stimulation tests were undertaken in all patients prior to starting $\mathrm{rGH}$ treatment. Baseline stimulated $\mathrm{GH}$ levels averaged $5.5 \mathrm{ng} / \mathrm{ml}$ (range: $2.0-8.7 \mathrm{ng} / \mathrm{ml}$ ). All patients had their bone age (BA) analysed with one results within normal limits (BA 5.0 years and chronological age [CA] 5.2 years). Five patients showed delayed BA (1. BA 3.5 years and CA 5.8 years; 2. BA 4.3 years and CA 4.9 years; 3. BA 8.0 years and CA 11.5 years; 4. BA 6.5 years and CA 8.1 years; 5. BA 6.0 years and CA 9.2 years). All patients were pre-pubertal prior to starting the treatment (Table II).

The mean treatment duration was 2.9 years (ranging from 2.5 to 8 years). The average starting dose of $\mathrm{rGH}$ treatment was 0.21 milligrams per kilogram per week (mg/kg/wk). The dose was adjusted during the course of treatment according to the respon$\mathrm{se}$, and the maximum mean dose was $0.22 \mathrm{mg} / \mathrm{kg} /$ day (range: $0.21-0.23 \mathrm{mg} / \mathrm{kg} / \mathrm{day}$ ). One patient required $\mathrm{rGH}$ dose reduction after 1.5 years of treatment due to high IGF-1 level - $505 \mathrm{ng} / \mathrm{ml}$ (range: 188-515). Following treatment, the mean IGF-1 improved to $217.5 \mathrm{ng} / \mathrm{ml}$ (range: $165-278 \mathrm{ng} / \mathrm{ml}$ ) after 1 year, and to $342 \mathrm{ng} / \mathrm{ml}$ (range: 212-482 ng/ml) after 2 years (Table III).

The mean baseline height was $-4.06 \mathrm{SD}$ (ranging from -6.3 to -2.3 ). After 1 year of treatment, the mean height improved to $-3.3 \mathrm{SD}$, which was statistically significant $(p=0.0021$, ranging from -4.9 to -1.9$)$. The mean height SD continued to improve at the end of 2 years following treatment, to $-3.03(p=0.0021$, ranging from -4.9 to -1.6 ; Table III).
Table I. Patients' characteristics

\begin{tabular}{ll}
\hline Patients' characteristics & Study cohort $(n=6)$ \\
\hline Gender, M : F & $1: 5$ \\
\hline Gestational age, weeks & $38[33-41]$ \\
\hline Preterm & $1(17)$ \\
\hline Weight at birth, SD & $-1.4[\mathrm{from}-2.46$ to -0.79$]$ \\
\hline Length at birth, SD & $0.4[\mathrm{from}-0.7$ to 1.4] \\
\hline Age at diagnosis, years & $5.5[0.7-12.5]$ \\
\hline Pancreatic insufficiency & $6(100)$ \\
\hline Neutropaenia & $6(100)$ \\
\hline Heart problems & $1(17)$ \\
\hline Skeletal abnormalities & $6(100)$ \\
\hline Hypothyroidism & $2(33)$ \\
\hline Congenital hypopituitarism & $1(17)$ \\
\hline
\end{tabular}

SD - standard deviation score

Values are $n, n$ (\%) or median [range]. The percentage is given in brackets and refers to the total count of patients.

The mean GV for the patients prior to starting treatment was $4.9 \mathrm{~cm} /$ year (ranging from 3.1 to $6.5 \mathrm{~cm} /$ year), which significantly improved to $7.6 \mathrm{~cm} /$ year (ranging from 5.7 to $9.6 \mathrm{~cm} /$ year) after 1 year of $\mathrm{GH}$ treatment $(p=0.02)$. The GV for the second year of therapy remained above baseline with an average of $6.7 \mathrm{~cm} /$ year ( $p=0.20$ compared to baseline GV; Table III).

\section{Discussion}

In the general population, growth deficiency occurs in 2.5\% of children, making it the most common reason for referral to a paediatric endocrinologist $[17,18]$. In daily clinical practice, the question of growth deficiency predictably arises in children with common genetic disorders such as Turner syndrome, Down syndrome, and Noonan syndrome [19], or better known diseases as Diamond-Blackfan anaemia [20]. The diagnosis of growth deficiency due to growth hormone deficiency (GHD) in children with other genetic disorders is challenging, partly due to the lack of a true gold standard, and the relatively poor correlation of growth and the genes residing in the critical chromosomal locus [21].SDS is a rare disease without a well-defined prevalence. Severe growth retardation (particularly in length/ height) is one of its typical features, which can be alleged to be linked to the genetic cause of the disease $[11,13,22]$. Metaphyseal chondrodysplasia, a well-known feature of SDS, may contribute to the shorter stature in about one-third of patients 
Table II. Baseline demographic data of SDS patients treated with rGH

\begin{tabular}{|c|c|c|c|c|c|c|}
\hline \multirow[t]{2}{*}{ Phenotypic information } & \multicolumn{6}{|l|}{ Subjects } \\
\hline & 1 & 2 & 3 & 4 & 5 & 6 \\
\hline Gender & $\mathrm{F}$ & $\mathrm{F}$ & $\mathrm{F}$ & $\mathrm{F}$ & $\mathrm{F}$ & $\mathrm{M}$ \\
\hline Age at rGH start, years & 5.8 & 4.9 & 11.5 & 5.2 & 8.1 & 9.2 \\
\hline Height, SD & -3.36 & -3.17 & -6.3 & -5.51 & -3.78 & -2.25 \\
\hline Bone age, years & 3.5 & 4.5 & 8.0 & 5.0 & 6.5 & 6.0 \\
\hline IGF-1, ng/ml & $\begin{array}{l}63.4 \\
(59-297)\end{array}$ & $\begin{array}{l}64.5 \\
(42-257)\end{array}$ & $\begin{array}{l}199 \\
(188-515)\end{array}$ & $\begin{array}{l}103 \\
(59-297)\end{array}$ & $\begin{array}{l}149 \\
(59-297)\end{array}$ & $\begin{array}{l}118 \\
(75-311)\end{array}$ \\
\hline IGFBP-3, $\mu \mathrm{g} / \mathrm{ml}$ & $\begin{array}{l}2.3 \\
(2.06-3.32)\end{array}$ & $\begin{array}{l}2.97 \\
(2.24-4.95)\end{array}$ & $\begin{array}{l}1.83 \\
(2.34-4.64)\end{array}$ & $\begin{array}{l}1.55 \\
(1.66-3.59)\end{array}$ & $\begin{array}{l}2.74 \\
(2.47-4.5)\end{array}$ & $\begin{array}{l}1.83 \\
(2.02-4.7)\end{array}$ \\
\hline Peak GH (stim test 1), ng/ml & 5 & 7.3 & 4.9 & 5.9 & 6.1 & 3.4 \\
\hline Peak GH (stim test 2), ng/ml & 7.9 & 6.3 & 4.7 & 8.7 & 2.0 & 4 \\
\hline Tanner stage & 1 & 1 & 1 & 1 & 1 & 1 \\
\hline $\mathrm{MPH}, \mathrm{SD}$ & 0.27 & -0.1 & 0.2 & -0.9 & -0.1 & 0.52 \\
\hline
\end{tabular}

rGH - recombinant human growth hormone; SD - standard deviation score; IGF-1 - insulin-like growth factor 1; IGF-BP3 - insulin-like growth factor binding protein 3; $\mathrm{GH}$ - growth hormone; $\mathrm{MPH}$ - mid parental height

Table III. The effect of growth hormone therapy on growth velocity and height standard deviation score

\begin{tabular}{|c|c|c|c|c|c|c|}
\hline \multirow[t]{2}{*}{ Phenotypic information } & \multicolumn{6}{|l|}{ Subjects } \\
\hline & 1 & 2 & 3 & 4 & 5 & 6 \\
\hline Gender & $\mathrm{F}$ & $\mathrm{F}$ & $\mathrm{F}$ & $\mathrm{F}$ & $\mathrm{F}$ & M \\
\hline Age at rGH start, years & 5.8 & 4.9 & 11.5 & 5.2 & 8.1 & 9.2 \\
\hline rGH start dose (mg/kg/week) & 0.2 & 0.2 & 0.23 & 0.23 & 0.2 & 0.2 \\
\hline Year 1 IGF-1 (ng/ml) & $\begin{array}{l}165 \\
(59-297)\end{array}$ & $\begin{array}{l}172 \\
(42-276)\end{array}$ & $\begin{array}{l}233 \\
(188-515)\end{array}$ & $\begin{array}{l}210 \\
(59-297)\end{array}$ & $\begin{array}{l}247 \\
(188-515)\end{array}$ & $\begin{array}{l}278 \\
(85-553)\end{array}$ \\
\hline Year 2 IGF-1 (ng/ml) & $\begin{array}{l}212 \\
(59-297)\end{array}$ & $\begin{array}{l}224 \\
(59-297)\end{array}$ & $\begin{array}{l}444 \\
(214-753)\end{array}$ & $\begin{array}{l}219 \\
(59-297)\end{array}$ & $\begin{array}{l}469 \\
(188-515)\end{array}$ & $\begin{array}{l}482 \\
(85-553)\end{array}$ \\
\hline Baseline GV (cm/year) & 5.1 & 5.6 & 3.1 & 6.5 & 5.0 & 4.0 \\
\hline Year 1 GV (cm/year) & 7.7 & 7.2 & 5.7 & 9.6 & 7.3 & 8.0 \\
\hline Year 2 GV (cm/year) & 7.5 & 6.8 & 5.6 & 6.7 & 5.9 & 7.6 \\
\hline Baseline height, SD & -3.36 & -3.17 & -6.3 & -5.51 & -3.78 & -2.25 \\
\hline Year 1 height, SD & -2.67 & -2.58 & -4.94 & -4.35 & -3.25 & -1.98 \\
\hline Year 2 height, SD & -2.31 & -2.24 & -4.91 & -3.98 & -3.16 & -1.58 \\
\hline
\end{tabular}

rGH - recombinant human growth hormone; SD - standard deviation score; GV - growth velocity; GH - growth hormone; MPH - mid parental height 
with SDS [10]. However, short stature in SDS should not be dismissed as simply part of the syndrome, as we identified growth hormone deficiency in 7 (37\%) of the 19 patients in our previous study. Similar to our results, Dealoprta et al. in the Greek Registry of Shwachman Diamond-Syndrome showed growth hormone deficiency in $3(27 \%)$ of the 11 patients requiring growth hormone therapy [13]. Additionally, rGH treatment has been previously reported in several cases $[10,11,13,14$, $23,24]$. One GHD patient who had associated hypogammaglobulinaemia responded to $\mathrm{rGH}$ treatment [23] and another did not [14]. Data regarding the effect of $\mathrm{rGH}$ therapy on final adult height in patients with SDS remains limited.

Jlvani et al. published in 2016 a unique case of SDS presenting with congenital hypopituitarism. A male infant was diagnosed with GHD and ACTH deficiency. Subsequently rGH (0.3 $\mathrm{mg} / \mathrm{kg} /$ week) and hydrocortisone treatment was started with good response and without any side effects [24]. Similarly to our findings, a girl was diagnosed with adrenal insufficiency during the diagnosis of hypoglycaemia and cholestasis at 3 months of age. Subsequently, hydrocortisone treatment was started. The endocrinologic evaluation due to short stature at the age of 4 years also showed GH deficiency, and rGH treatment was started (patient no. 4, Tables II and III). She was also diagnosed with thoracic dystrophy, which resulted in a preliminary mistaken diagnosis of Jeune syndrome. Schaballie et al. in 2013 conducted a retrospective study describing 11 Belgian patients with genetically confirmed diagnosis of SDS. The authors presented 4 out of 11 patients who were misdiagnosed as having asphyxiating thoracic dystrophy (Jeune syndrome) because of severe thoracic dystrophy [25].

To the best of our knowledge, this study is the first analysis of the effect of growth hormone therapy in children with SDS. The results of the study show that the height SD in patients with SDS significantly improved in the first 2 years of GH therapy compared to baseline. GV improved significantly during the first year of $\mathrm{GH}$ treatment and remained higher than baseline for the second year.

In 2017 Delaporta et al. undertook a study in a cohort of 11 patients registered in the Greek Registry of Shwachman Diamond-Syndrome. Similarly to our results, the authors described 2 patients who received the treatment around puberty with moderate response [13].

Typical skeletal changes are present in all patients with SDS; however, their severity and location change with age [26]. In the analysed group, all the patients had skeletal changes, but only 4 presented such abnormalities in the physical examination. The characteristic changes included delayed appearance of secondary ossification centres, metaphyseal dysostosis, and generalized osteopaenia [26]. All the patients in the cohort showed osteopaenia in the bone mineral density measurements. According to Rosendahl et al. and Toiviainen-Salo et al., who studied bone mineral density, bone biopsies, and vitamin $\mathrm{D}$ and $\mathrm{K}$ status in SDS patients, there is a primary defect of bone metabolism in children affected with SDS [27, 28]. Screening for bone mineral density and vitamin $D$ level should be performed in all SDS patients. The delayed bone age assessed in $5(83 \%)$ of our SDS patients, similarly to Schaballie et al. findings [25], improved the prediction of their final height.

In other genetic syndromes rGH therapy has shown benefit, particularly when initiated at an early age. Patients with earlier age at $\mathrm{rGH}$ initiation and longer duration of rGH therapy demonstrated the best results of treatment [29]. Similarly, growth hormone initiation in early childhood has been shown to improve not only height but also body composition, lipid profiles, and intestinal absorption. The explanation of these findings is connected with proliferative effects of $\mathrm{GH}$ upon intestinal epithelium. It also influences enteroendocrine cell secretion calcium absorption, and intestinal amino acid and ion transport [30].

Finally, potential concerns have been raised about the safety of $\mathrm{rGH}$ treatment in patients with SDS, especially in those with bone marrow aplasia. SDS is characterized by a high propensity for the development of myelodysplastic syndrome (MDS) and leukaemia, specifically acute myelogenous leukaemia (AML) - with an estimated risk of $36 \%$ at age 30 years [31]. All the patients in our study tolerated the medication well and were regularly followed up by an immunologist, a gastroenterologist, and an endocrinologist. No specific side effects related to $\mathrm{rGH}$ treatment were noted in these patients. The reviews and studies discussed have also demonstrated $\mathrm{GH}$ therapy to be safe with no significant side effects $[13,23,24]$. $\mathrm{rGH}$ has been thought to trigger proliferation of normal and malignant cells. Current literature has not found an association between $\mathrm{GH}$ therapy and increased risk of malignant disorders in patients who are not more likely to be predisposed to cancer from a genetic condition [32]. Potential risks and benefits of rGH therapy should be carefully considered prior to treatment. Growth hormone treatment should be conducted to maintain serum IGF-1 in the mid-normal range for age. There are only limited data regarding the increased risk of cancer in patients with SDS, who are treated with $\mathrm{rGH}$. A retrospective report on the long-term effects of $\mathrm{rGH}$ therapy in patients with SDS is needed to assess the efficiency and safety of GH treatment.

\section{Conclusions}

Growth hormone treatment in children with SDS significantly improves both GV and height SD during treatment sustained for up to 3 years. Very short children with SDS can be treated successfully with $\mathrm{GH}$ to restore stature to levels comparable to less affected patients. Careful consideration of the individualized benefit of $\mathrm{rGH}$ therapy versus risk is important in view of the long-term underlying malignancy risk in SDS. Further research is required to understand the impact of $\mathrm{rGH}$ on final adult height.

\section{Acknowledgements}

The authors want to thank all participating colleagues for recruiting patients, and the patients and their parents for participating in this study. 
Bogusz-Wójcik A., Kołodziejczyk H., Elżbieta Moszczyńska, Klaudel-Dreszler M., Oracz G., Pawłowska J., Szalecki M.

\section{References}

1. Dror Y, Donadieu J, Koglmeier J, et al. Draft consensus guidelines for diagnosis and treatment of shwachman-diamond syndrome. Ann N Y Acad Sci 2011; 1242: 40-55. doi: 10.1111/j.1749-6632. 2011.06349.x.

2. Donadieu J, Leblanc T, Meunier BB, et al. Analysis of risk factors for myelodysplasias, leukemias and death from infection among patients with congenital neutropenia. Experience of the French Severe Chronic Neutropenia Study Group. Haematologica. 2005; 90: 45-53.

3. Boocock GRB, Morrison JA, Popovic M, et al. Mutations in SBDS are associated with Shwachman-Diamond syndrome. Nat Genet 2003; 33: 97-101. doi: 10.1038/ng1062.

4. Bezzerri V, Cipolli M. Shwachman-Diamond Syndrome: Molecular Mechanisms and Current Perspectives. Mol Diagnosis Ther 2019; 23: 281-290. doi: 10.1007/s40291-018-0368-2.

5. Dhanraj S, Matveev A, Li H, et al. Biallelic mutations in DNAJC21 cause Shwachman-Diamond syndrome. Blood 2017; 129: 15571562. doi: 10.1182/blood-2016-08-735431.

6. Stepensky P, Chacón-Flores M, Kim KH, et al. Mutations in EFL1, an SBDS partner, are associated with infantile pancytopenia, exocrine pancreatic insufficiency and skeletal anomalies in a Shwachman -Diamond like syndrome. J Med Genet 2017; 54: 558-566. doi: 10.1136/jmedgenet-2016-104366.

7. Carapito R, Konantz M, Paillard C, et al. Mutations in signal recognition particle SRP54 cause syndromic neutropenia with Shwachman-Diamond-like features. J Clin Invest 2017; 127: 4090-4103. doi: $10.1172 / \mathrm{JCl} 92876$.

8. Cipolli M. Shwachman-Diamond Syndrome: Clinical Phenotypes. Pancreatology 2001; 1: 543-548. doi: http://dx.doi.org/10.1159/ 000055858

9. Bogusz-Wójcik A, Kołodziejczyk H, Klaudel-Dreszler M, et al. Somatic development in children with Shwachman-Diamond syndrome. Ital J Pediatr 2020; 46: 151. doi: 10.1186/s13052-020-00919-z.

10. Myers KC, Rose SR, Rutter MM, et al. Endocrine evaluation of children with and without Shwachman-Bodian-Diamond syndrome gene mutations and Shwachman-Diamond syndrome. J Pediatr 2013; 162: 1235-1240. doi: 10.1016/j.jpeds.2012.11.062.

11. Cipolli M, Tridello G, Micheletto A, et al. Normative growth charts for Shwachman-Diamond syndrome from Italian cohort of 0-8 years old. BMJ Open 2019; 9: e022617. doi: 10.1136/bmjopen-2018-022617.

12. Bogusz-Wójcik A, Kołodziejczyk H, Moszczyńska E, et al. Endocrine dysfunction in children with Shwachman-Diamond syndrome. Endokrynol Pol 2021. doi: 10.5603/EP.a2021.0014.

13. Delaporta P, Sofocleous C, Economou M, et al. The Greek Registry of Shwachman Diamond-Syndrome: Molecular and clinical data. Pediatr Blood Cancer 2017; 64: 10-13. doi: 10.1002/pbc.26630.

14. Goeteyn M, Oranje AP, Vuzevski VD, et al. Ichthyosis, exocrine pancreatic insufficiency, impaired neutrophil chemotaxis, growth retardation, and metaphyseal dysplasia (Shwachman syndrome). Report of a case with extensive skin lesions (clinical, histological, and ultrastructural findings). Arch Dermatol 1995; 96: 225-230.

15. Palczewska I, Niedzwiedzka Z. Wskaźniki rozwoju somatycznego dzieci I młodziezy Warszawskiej [Somatic development indices in children and youth of Warsaw]. Med Wieku Rozwoj 2001; 5 (2 Suppl 1): 18-118.

16. Wejnarska K, Kołodziejczyk E, Ryżko J, Oracz G. Comparison of 72-hour fecal fat quantification and the 13C-mixed triglyceride breath test in assessing pancreatic exocrine sufficiency in children with chronic pancreatitis. Dev Period Med 2016; 20: 222-227.

17. Teran E, Chesner J, Rapaport R. Growth and growth hormone: An overview. Growth Horm IGF Res 2016; 28: 3-5. doi: 10.1016/j. ghir.2016.02.004

18. Collett-Solberg PF, Ambler G, Backeljauw PF, et al. Diagnosis, Genetics, and Therapy of Short Stature in Children: A Growth Hormone Research Society International Perspective. Horm Res Paediatr 2019; 92: 1-14. doi: 10.1159/000502231.

19. Seo GH, Yoo HW. Growth hormone therapy in patients with noonan syndrome. Ann Pediatr Endocrinol Metab 2018; 23: 176-181. doi: 10.6065/apem.2018.23.4.176.

20. Howell JC. Growth hormone improves short stature in children with Diamond Blackfan anemia. Pediatr Blood Cancer 2015; 62: 402-408. doi: 10.1002/pbc.25341.

21. Franciskovich R, Soler-Alfonso C, Neira-Fresneda J, et al. Short stature and growth hormone deficiency in a subset of patients with Potocki-Lupski syndrome: Expanding the phenotype of PTLS. Am J Med Genet Part A 2020; 182: 2077-2084.

22. Myers KC, Bolyard AA, Otto B, et al. Variable clinical presentation of shwachman-diamond syndrome: Update from the North American shwachman-diamond syndrome registry. J Pediatr [Internet] 2014; 164: 866-870. doi: 10.1016/j.jpeds.2013.11.039.

23. Kornfeld SJ, Kratz J, Diamond F, et al. Shwachman-Diamond syndrome associated with hypogammaglobulinemia and growth hormone deficiency. J Allergy Clin Immunol 1995; 96: 247-250. doi: 10.1016/s0091-6749(95)70014-5.

24. Jivani N, Torrado-Jule C, Vaiselbuh S, Romanos-Sirakis E. A unique case of Shwachman-Diamond syndrome presenting with congenital hypopituitarism. J Pediatr Endocrinol Metab 2016; 29: 13251327. doi: 10.1515/jpem-2016-0299.

25. Schaballie H, Renard M, Vermylen C, et al. Misdiagnosis as asphyxiating thoracic dystrophy and CMV-associated haemophagocytic lymphohistiocytosis in Shwachman-Diamond syndrome. Eur J Pediatr 2013; 172: 613-622. doi: 10.1007/s00431-012-1908-0.

26. Mäkitie O, Ellis L, Durie PR, et al. Skeletal phenotype in patients with Schwachman-Diamond syndrome and mutations in SBDS. Clin Genet 2004; 65: 101-112. doi: 10.1111/j.0009-9163.2004.00198.x.

27. Toiviainen-Salo S, Mäyränpää MK, Durie PR, et al. ShwachmanDiamond syndrome is associated with low-turnover osteoporosis. Bone 2007; 41: 965-972. doi: 10.1016/j.bone.2007.08.035.

28. Rosendahl J, Teich N, Mössner J, et al. Compound heterozygous mutations of the SBDS gene in a patient with Shwachman-Diamond syndrome, type 1 diabetes mellitus and osteoporosis. Pancreatology 2006; 6: 549-554. doi: 10.1159/000096978.

29. Collett-Solberg PF, Ambler G, Backeljauw PF, et al. Diagnosis, Genetics, and Therapy of Short Stature in Children: A Growth Hormone Research Society International Perspective. Horm Res Paediatr. 2019; 92: 1-14. doi: 10.1159/000502231.

30. Shulman DI. Gastrointestinal effects of growth hormone. Endocrine 2000; 12: 147-152.

31. Dale DC, Bolyard AA, Schwinzer BG, et al. The Severe Chronic Neutropenia International Registry: 10-Year follow-up report. Support Cancer Ther [Internet] 2006; 3: 220-231. doi: 10.3816/SCT.2006.n.020.

32. Burroughs L, Woolfrey A, Shimamura A. Shwachman-Diamond syndrome: a review of the clinical presentation, molecular pathogenesis, diagnosis, and treatment. Hematol Oncol Clin North Am 2009; 23: 233-248. doi: 10.1016/j.hoc.2009.01.007. 